\title{
Reproductive Season of the Scalloped Spiny Lobster Panulirus homarus Along the Coast of Oman: Management Implications
}

\author{
Abdulaziz Al-Marzouqi*1, Johan C. Groeneveld'1, Abdullah Al-Nahdi' \\ and Ahmed Al-Hosni² \\ ${ }^{1}$ Marine Science and Fisheries Centre, P.O. Box 227 \\ PC 100, Muscat, Sultanate of Oman \\ ${ }^{2}$ Ministry of Fisheries Wealth, P.O. Box 427 \\ PC 100, Muscat, Sultanate of Oman
}

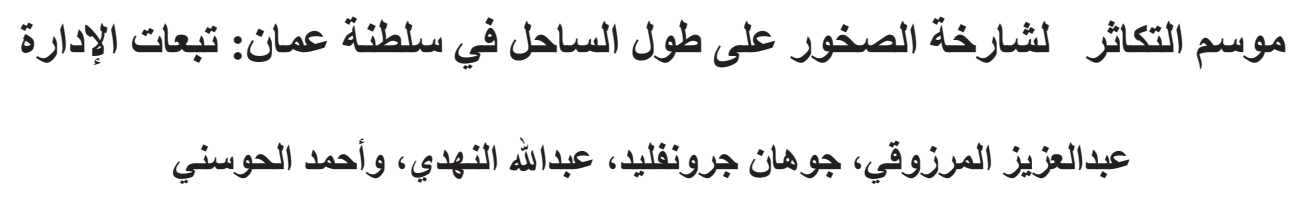

الخلاصة: تتوزع شارخة الصخور (Panulirus homarus) في منطقة المحيط الهندي و غرب المحيط الهادي، وتتو اجد الشارخة

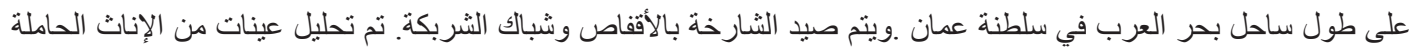

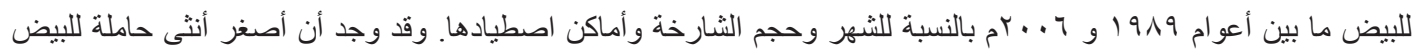

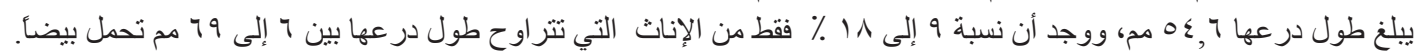

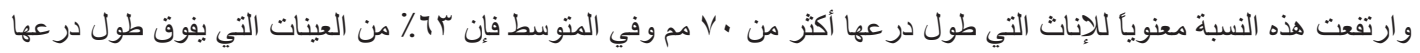

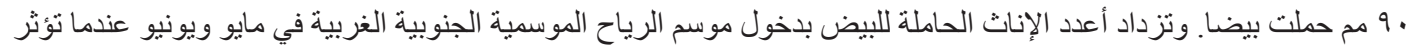

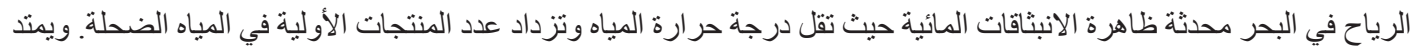

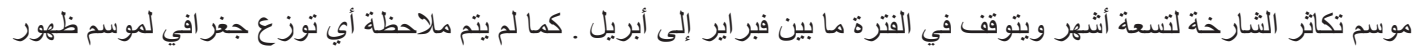

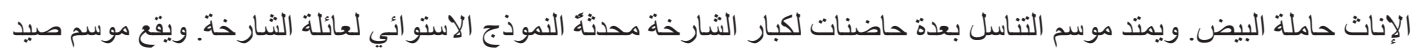

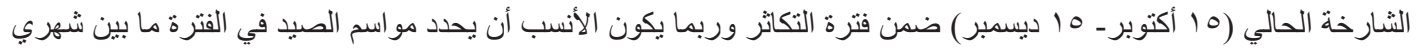
فبر اير و أبريل.

\begin{abstract}
The spiny lobster Panulirus homarus is widely distributed in the Indo-West Pacific. Along the coast of Oman it supports an artisanal fishery using traps and tangle nets. The egg-bearing incidence of females caught between 1989 and 2006 were analysed relative to month, lobster size and location of capture. The smallest female with external eggs had a carapace length (CL) of $54.6 \mathrm{~mm}$, but only $9-18 \%$ of females of $60-69 \mathrm{~mm}$ CL carried eggs. This percentage increased significantly above $70 \mathrm{~mm} \mathrm{CL}$, and on average, $63 \%$ of individuals $>90 \mathrm{~mm}$ carried eggs. Egg-bearing increased seasonally at the onset of the SW monsoon in May and June, when wind-driven upwelling reduces inshore water temperatures and increases primary productivity. The reproductive season extended over a 9-month period up to January, with a pause in February to April. No geographical gradient in egg-bearing seasonality was observed. The prolonged breeding season with multiple broods in large females conforms with the typical pattern of tropical palinurids. The 2 -month open fishing season $\left(15^{\text {th }}\right.$ October to $15^{\text {th }}$ December) falls within the breeding season, and may be more optimally placed in February to April.
\end{abstract}

Keywords: Panulirus homarus, reproductive season, Oman 


\section{Introduction}

The scalloped spiny lobster Panulirus homarus is widely distributed in the tropical and subtropical waters of the Indo-West Pacific, where it occurs in coastal waters (1-90 m depth) from eastern South Africa to Somalia (including Madagascar), along the Arabian Peninsula, and from India and Indonesia to Japan and Australia (Holthuis, 1991). Along the Arabian Peninsula, it occurs in the Gulf of Aden, and extends into the Arabian Sea along the coasts of Yemen and Oman, up to Ras al Hadd (approx. $22^{\circ} \mathrm{N}$ ), but is uncommon in the Gulf of Oman and absent from the Arabian Gulf (Al-Abdessalaam, 1995). Panulirus homarus inhabits coral and rocky areas, where it may co-occur with other tropical and subtropical spiny lobster species, i.e. $P$. ornatus, $P$. versicolor, $P$. longipes and P. penicillatus (Holthuis, 1991).

The nearshore distribution of $P$. homarus along the coast of Oman makes it easily accessible to traditional (artisanal) fishers using traps and tangle nets from small (4-11 m length) motorized fibreglass boats. At least 3000 boats land lobster periodically along the Arabian Sea coastline south of Ras al Hadd (a distance of approximately $1100 \mathrm{~km}$ ), although these boats also target other fish and cephalopod species (Anon., 2006). Reported lobster landings from Oman have declined from over $2000 \mathrm{t} / \mathrm{yr}$ in the 1980's to between 200 and $500 \mathrm{t} / \mathrm{yr}(2000-2006)$ although these statistics almost certainly underestimate the actual catch. The declines in lobster catches reflect a general trend in the northwestern Indian Ocean region, and have been attributed to destructive fishing methods and overfishing (Siddeek, 1999; Radhakrishnan et al., 2005; Al-Marzouqi et al., 2007).

Most of the catches from Oman are exported to Dubai (United Arab Emirates) and other international markets to earn foreign exchange of approximately \$US 3-5 million per year. The present lobster management regulations include a 2-month open fishing season extending from $15^{\text {th }}$ October to $15^{\text {th }}$ December, a minimum legal size (MLS) of $80 \mathrm{~mm}$ carapace length, a ban on marketing egg-bearing females and a restriction of gear to governmentapproved traps, however these regulations are not strictly enforced (Mohan, 1997; Al-Marzouqi et al., 2007).

Female $P$. homarus in the waters of Oman reach sexual maturity at a size of $\sim 65 \mathrm{~mm}$ carapace length approximately 2 years after settling as pueruli on the seabed, and can attain a maximum size of $120-125$ $\mathrm{mm}$ after 8-10 years (Al-Marzouqi et al., 2007). The species breed repetitively during the year; four broods/year were observed off eastern South Africa (Berry, 1971) and captive specimens in India produced four broods on average, with a maximum of seven (Vijayakumaran et al., 2005). The frequency of eggbearing and brood size increases steeply with lobster size, and large females are highly fecund ( $\sim 2$ million eggs/year; Vijayakumaran et al., 2005).

Female $P$. homarus may carry eggs throughout the year (Vijayakumaran et al., 2005), although Berry (1971) showed a peak in breeding activity over the austral spring and summer in South-Africa. Johnson and Al-Abdulsalaam (1991) found that egg-bearing females in Oman occurred in all months of the year for which they had data (September-February), but noted that there were distinct peaks which varied among regions. The aim of this study was to define the breeding season of $P$. homarus in Oman based on the monthly proportions of egg-bearing females in samples collected between 1989 and 2006. The key questions asked were whether a seasonal breeding peak could be shown, and what the influence of lobster size and geographic location had on the egg-bearing proportions. The results of this study provide fisheries managers with information on which to base the timing and duration of the open fishing season.

\section{Materials and Methods}

Lobsters landed by commercial fishers at landing sites between Ras al Hadd and Dalkut (Fig. 1) were sampled during the annual 2-month open fishing seasons between 1989 and 2006, and additional catches made outside of these months were sampled whenever available. Data were treated separately for the 19892002 (historical) and 2003-2006 (recent) periods, because the open fishing season was moved from December/January to mid-October/mid-December in 2003. The carapace length $(\mathrm{CL} \pm 0.1 \mathrm{~mm})$ of female lobsters was measured mid-dorsally from the transverse ridge between the frontal spines and posterior carapace edge, and the presence / absence of external eggs on the abdomen recorded. Eggs were staged visually as follows (see Berry, 1971): Stage 1 - freshly extruded eggs, round and bright orange with no embryonic development visible macroscopically; Stage 2 - early embryonic development with egg colour becoming deep orange to brownish, eyespots faintly visible; Stage 3 - well-formed embryo, eggs slightly oval and brown due to growth of embryo and 


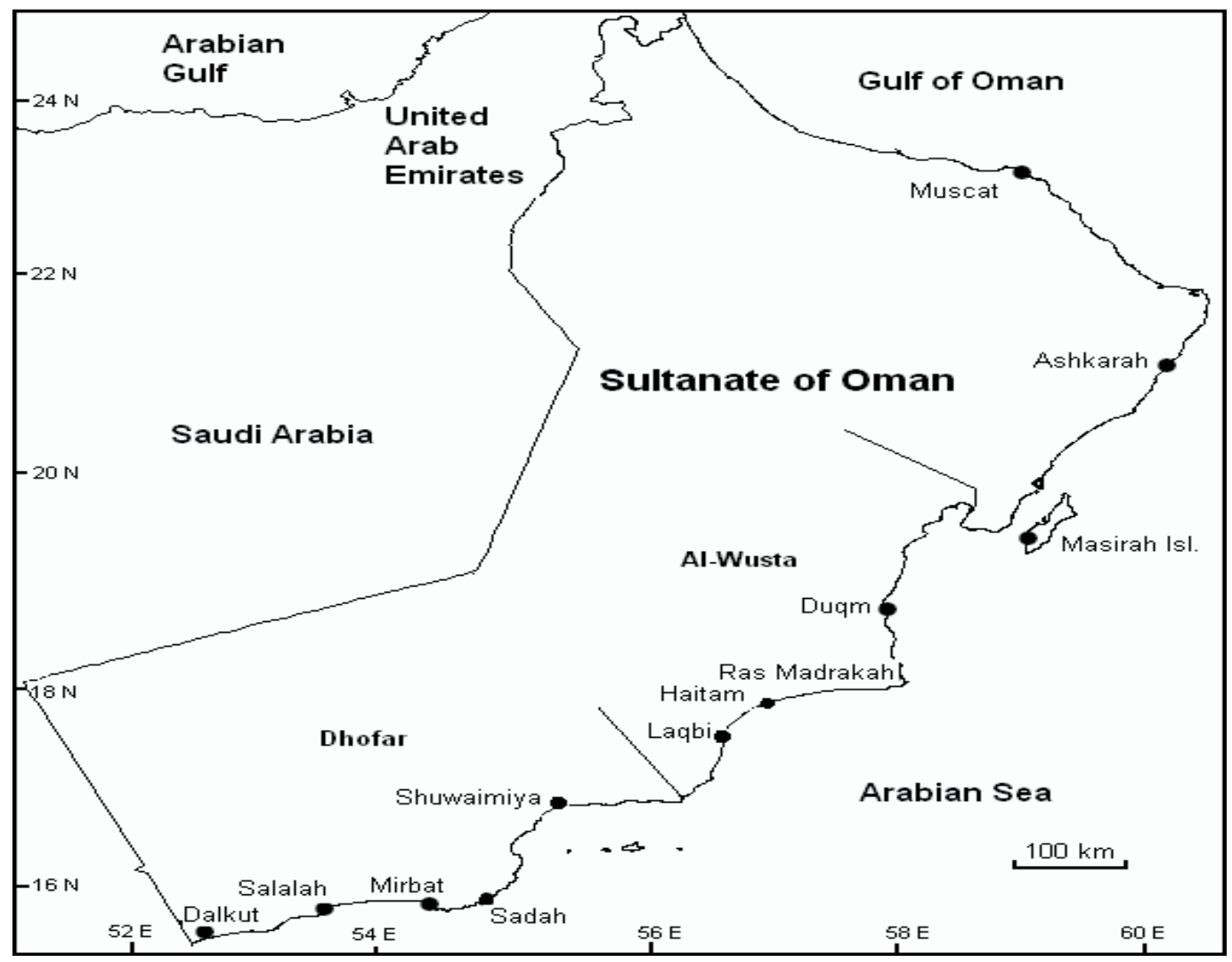

Figure 1. The Sultanate of Oman, showing the sampling sites along the Arabian Seas coastline.

reduction of orange yolk, eyespots conspicuous; Stage 4 - eggs hatched with ovigerous setae a mass of eggstalks and empty capsules. These are detached by the female within a few days.

The proportions of females carrying eggs, relative to all females caught within the length classes $<60$ $\mathrm{mm}, 60-69 \mathrm{~mm}, 70-79 \mathrm{~mm}, 80-89 \mathrm{~mm}$ and $>90 \mathrm{~mm}$ $\mathrm{CL}$, were calculated for each year, month and area. Comparisons between length classes were done using a contingency table analysis for binomial distributions ( $\chi^{2}$-tests; Zar, 1984). Females were grouped into month $\times$ size categories to assess seasonal egg-bearing trends.

For the spatial analysis, data were available from landing sites in Dhofar (Dalkut, Mughsayl, Mirbat, Sadah, Shuwaimiya and Hadbin), and in Al-Wusta (Laqbi, Hitam, Ras Madrakah and Masira) (Fig. 1). Only data collected during the peak egg-bearing season were used (December only for 1989-2002;
October-December for 2003-2006), grouped into year $\times$ month $\times$ site $\times$ size categories and compared using similar $\chi^{2}$-tests than shown above..

\section{Results}

The size of female lobsters sampled ranged from 35.0-124.1 mm (mean CL=75.4 \pm 11.8 [SD] mm, $\mathrm{n}=$ 20336 ) (Table 1), and the smallest individual carrying eggs was $54.6 \mathrm{~mm}$. Less than $1 \%$ of females $<60 \mathrm{~mm}$ CL carried eggs, and in the $60-69 \mathrm{~mm}$ length-class egg-bearing remained low at $9-18 \%$ (Fig. 2). The majority of females in these length classes may still be immature (see also Al-Marzouqi et al., 2007), and all females $<70 \mathrm{~mm}$ CL were therefore excluded from further analyses.

The proportions of females carrying eggs increased significantly with increasing lobster size above $70 \mathrm{~mm}$ $\mathrm{CL}$ ( $\chi^{2}$-tests, $\mathrm{p}<0.05$; Fig. 2). Egg-bearing proportions were also significantly higher in samples collected 
Table 1. The total number of female lobsters sampled per year (n), CL range and average CL ( \pm S.D.) and the total number of egg-bearing females recorded. Percentage egg-bearing is shown in parenthesis.

\begin{tabular}{lccccccc}
\hline Year & $\begin{array}{c}\text { Sample } \\
\text { size (n) }\end{array}$ & $\begin{array}{c}\text { Min CL } \\
(\mathbf{m m})\end{array}$ & $\begin{array}{c}\text { Max CL } \\
(\mathbf{m m})\end{array}$ & $\begin{array}{c}\text { AvgCL } \\
(\mathbf{m m})\end{array}$ & $\begin{array}{c}\text { SD } \\
(\mathbf{m m})\end{array}$ & \multicolumn{2}{c}{ Egg-bearing } \\
$(\mathbf{n})$ & $\mathbf{( \% )}$ \\
\hline 1989 & 742 & 39.9 & 115.0 & 80.1 & 12.4 & 114 & 15.4 \\
1991 & 460 & 36.7 & 104.1 & 76.6 & 12.0 & 55 & 12.0 \\
1992 & 1131 & 46.5 & 109.8 & 76.8 & 10.5 & 204 & 18.0 \\
1993 & 1366 & 41.0 & 115.0 & 78.2 & 11.0 & 414 & 30.3 \\
1994 & 1465 & 36.9 & 115.8 & 79.4 & 12.0 & 605 & 41.3 \\
1995 & 1135 & 46.2 & 116.1 & 78.7 & 11.4 & 511 & 45.0 \\
1996 & 920 & 43.1 & 111.4 & 78.0 & 10.9 & 300 & 32.6 \\
1997 & 609 & 46.4 & 111.8 & 78.0 & 11.4 & 206 & 33.8 \\
1998 & 333 & 42.0 & 107.0 & 74.4 & 11.3 & 124 & 37.2 \\
1999 & 797 & 44.2 & 119.0 & 78.9 & 11.0 & 275 & 34.5 \\
2000 & 470 & 40.2 & 110.7 & 75.4 & 14.9 & 160 & 34.0 \\
2001 & 709 & 41.3 & 119.1 & 78.8 & 12.8 & 226 & 31.9 \\
2002 & 128 & 39.6 & 98.5 & 68.0 & 11.9 & 33 & 25.8 \\
2003 & 900 & 50.2 & 116.6 & 75.8 & 8.2 & 373 & 41.4 \\
2004 & 3185 & 35.2 & 124.1 & 74.5 & 13.3 & 1242 & 39.0 \\
2005 & 4290 & 35.0 & 116.1 & 70.9 & 10.6 & 1308 & 30.5 \\
2006 & 1696 & 40.6 & 118.0 & 77.3 & 9.2 & 617 & 36.4 \\
\hline
\end{tabular}

between 2003 and 2006 than in those collected between 1989 and 2002 in equivalent length classes $\left(\chi^{2}\right.$-tests, $p<0.05$; Fig. 2), perhaps reflecting the shift in the open fishing season (and therefore in the sampling schedule) after 2002.
No monthly samples were available for July to September in any year, because no fishing takes place during these months of adverse sea conditions (Fig. 3). The raw data (proportions in month $\times$ size combinations) showed relatively lower values in February to April

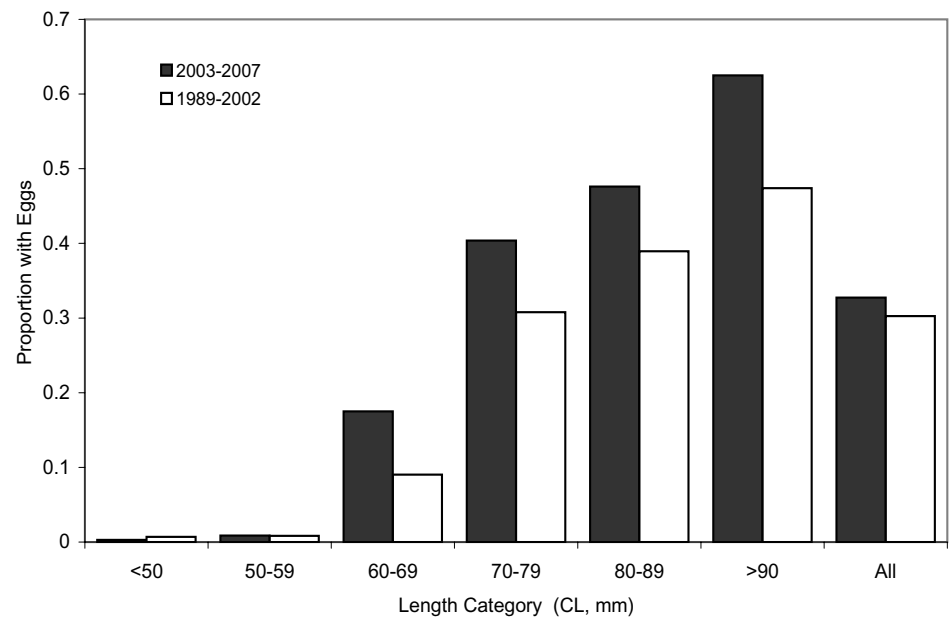

Figure 2. The proportions of all female Panulirus homarus sampled with eggs in each size class (CL, $\mathrm{mm}$ ) for the historic (1989-2002) and recent (2003-2006) periods of this study. 


\section{0-79 $\mathrm{mm} \mathrm{CL}$}

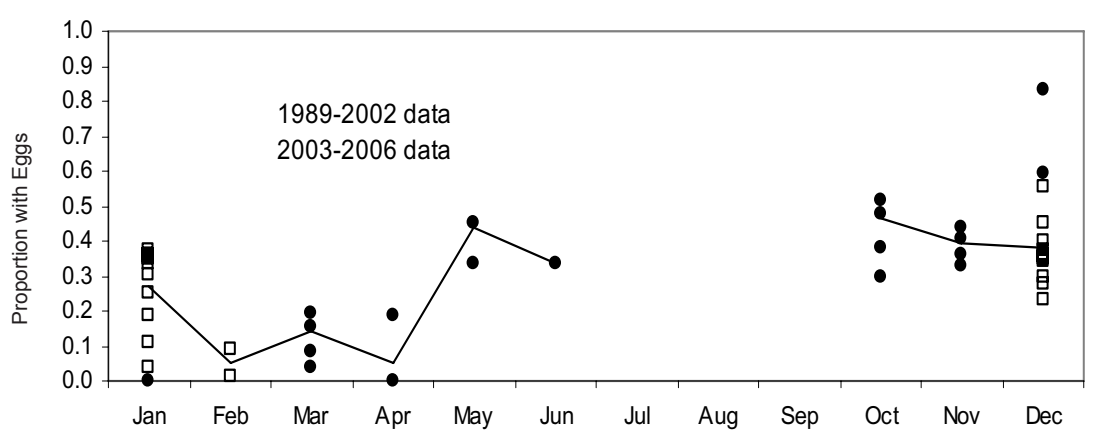

80-89mm CL

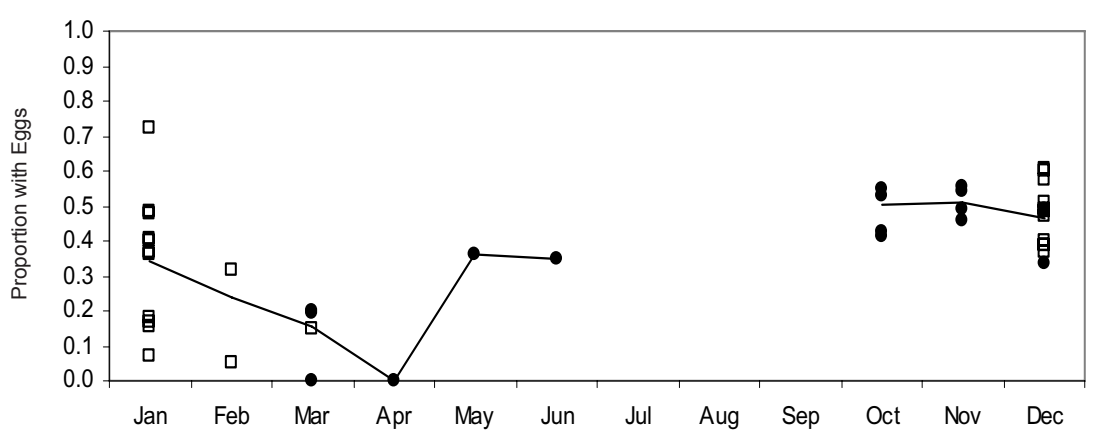

$>90 \mathrm{~mm} \mathrm{CL}$

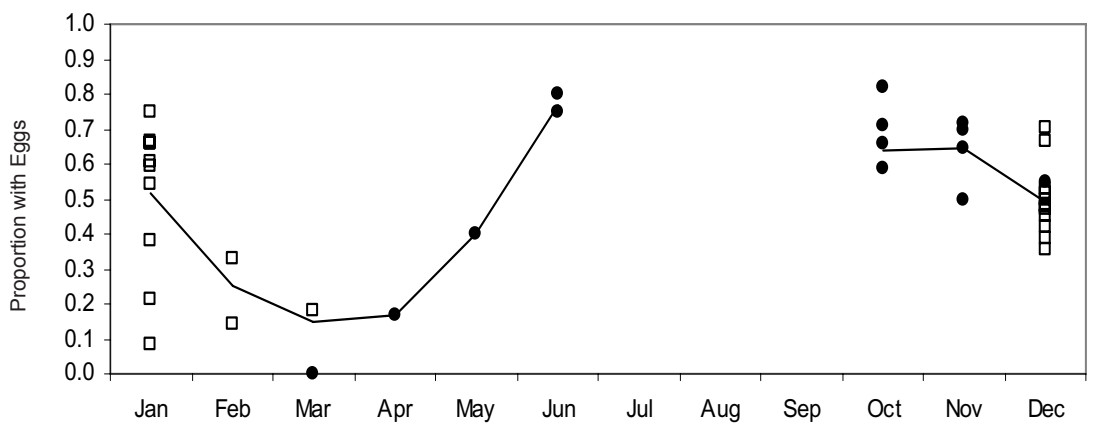

Figure 3. The monthly proportions of all females sampled with eggs (all data, year $\times$ month combinations) and the overall monthly egg-bearing trend in size classes (a) 70-79 mm, (b) 80-89 mm and (c) >90 mm CL. Open squares denote samples taken in 1989-2002 and filled circles denote 2003-2006 data. Samples were not available for some months in each year. 
Table 2. Results of Chi-square tests for the null hypothesis that egg-bearing proportions are the same for all sites within each year of sampling. $\mathrm{n} 1$ and $\mathrm{n} 2$ are the numbers of sites compared, * indicates $\mathrm{p}<0.05$, and pooled values are shown.

\begin{tabular}{cccclccc}
\hline Year & $\mathbf{n 1}$ & $\mathbf{X}^{\mathbf{2}}$ & $\begin{array}{c}\text { Pooled egg- } \\
\text { bearing prop. }\end{array}$ & $\begin{array}{c}\text { Sites } \\
\text { eliminated }\end{array}$ & $\mathbf{n 2}$ & $\mathbf{X}^{2}$ & $\begin{array}{c}\text { Pooled egg- } \\
\text { bearing prop. }\end{array}$ \\
\hline 1993 & 6 & $22.02 *$ & & Dalkut & 5 & 7.05 & 0.38 \\
1994 & 5 & $32.88^{*}$ & & Dalkut, Mirbat & 3 & 4.29 & 0.59 \\
1995 & 4 & $18.31 *$ & & Shuwaimiya & 3 & 4.53 & 0.66 \\
1996 & 5 & 2.39 & 0.37 & & & & \\
1997 & 4 & $28.69 *$ & & Mughsayl & 3 & 2.97 & 0.46 \\
1999 & 4 & 1.98 & 0.43 & & & & \\
2000 & 2 & 0.001 & 0.47 & & & & \\
2001 & 4 & $10.28 *$ & & Mughsayl & 3 & 2.02 & 0.45 \\
2003 & 4 & 4.56 & 0.47 & & & & \\
2004 & 6 & $229.98 *$ & & Mirbat, Hitam & 4 & 3.75 & 0.57 \\
2005 & 3 & $9.36 *$ & & Sadah & 2 & 2.03 & 0.53 \\
2006 & 3 & $110.4 *$ & & & & & \\
\hline
\end{tabular}

compared to May and June, and October to January. In January, values were scattered between zero and 0.75 , suggesting particularly high interannual variability during this month. Higher values were generally obtained for females $>90 \mathrm{~mm} \mathrm{CL}$. Combining all the data from 1989-2006 into trends suggested that fewer females bore eggs in February to April than in any other month, and that egg-bearing increased through May and June (Fig. 3). Although this trend was similar for all three size classes tested, females $>90 \mathrm{~mm} \mathrm{CL}$ had a much higher egg-bearing incidence in June, suggesting that they start carrying eggs earlier in the season than smaller females.

The null hypothesis stating that egg-bearing proportions would be the same for all sites tested for the same period within each year (i.e. year $\times$ month $\times$ site $\times$ size comparisons) was accepted for four out of 12 years tested (1996, 1999, 2000, 2003; see Table 2), and for an additional five years it was accepted after eliminating a single site. No sitespecific trends emerged across years (Fig. 4), apart from Hitam where the two lowest values $(6 \%$ and $7 \%$ in 2004 and 2006) were observed. The conclusion is therefore that egg-bearing proportions are similar among sites for a given period within a year, but with some variability.

Of 6854 egg-bearing females, 3973 (58\%) carried eggs in stage 1 , followed by 1438 (21\%) in stage 2 ,
$1069(16 \%)$ in stage 3 and $374(5 \%)$ in stage 4 . The small proportion in stage 4 possibly reflects the short time window (days only) between hatching and the detachment of spent egg-stalks and setae. Stage 1 eggs were most frequent in all months except March and June, when there were more females carrying stage 2 and 3 eggs (Fig. 5). The sharp increase in stage 1 eggs between March and May, followed by the large proportion of stage 2 eggs in June is noteworthy, and suggests a synchronized onset of the reproductive season, with females becoming egg-bearing in May (i.e. the highest stage 1 frequency of all months) and progressing to stage 2 by June.

\section{Discussion}

The analysis of the aggregated database for the 1989-2006 period provided clear answers to the three questions asked at the onset of this study, namely that: a) the incidence of egg-bearing increases in May and June after low activity in February to April, and a higher incidence also occurs in October to January; b) egg-bearing is size dependent with females $>90$ $\mathrm{mm}$ CL bearing eggs more frequently than smaller individuals; and c) most sites show a similar seasonal pattern.

No data were available for July to September (the later part of the SW monsoon season), and it is therefore unsure whether the higher egg-bearing 

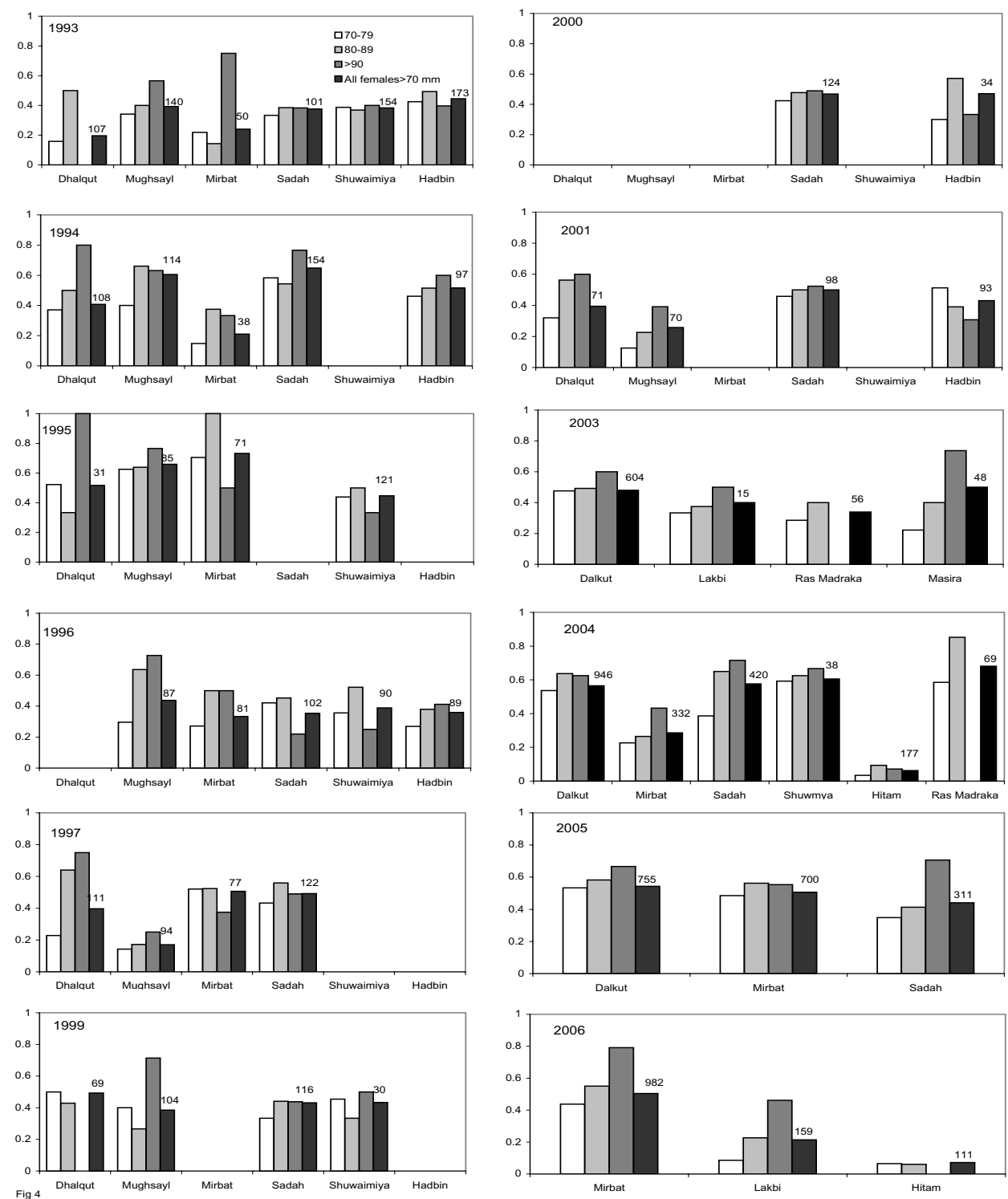

Figure 4. The proportions of all females sampled with eggs per site in each year (year $\times$ month $\times$ site $\times$ size combinations). Data consist of all females sampled in December in 1989-2002 and all females sampled in October-December in 2003-2006, and sample sizes per site are shown.

incidence observed in May/June extends to these months. However, of 49 egg-bearing females in an additional sample taken in October 2007, 27\% were in Stage 4 and another $24 \%$ in Stage 3. Therefore a large proportion of females must have been in the early egg-bearing stages one to two months earlier (i.e. in August and September), considering that the incubation period of this species is between 20 and 37 days (Vijayakumaran et al., 2005). It therefore appears as if the egg-bearing incidence is also high between August and September, and that $P$. homarus in Oman has a protracted breeding season that stretches from 


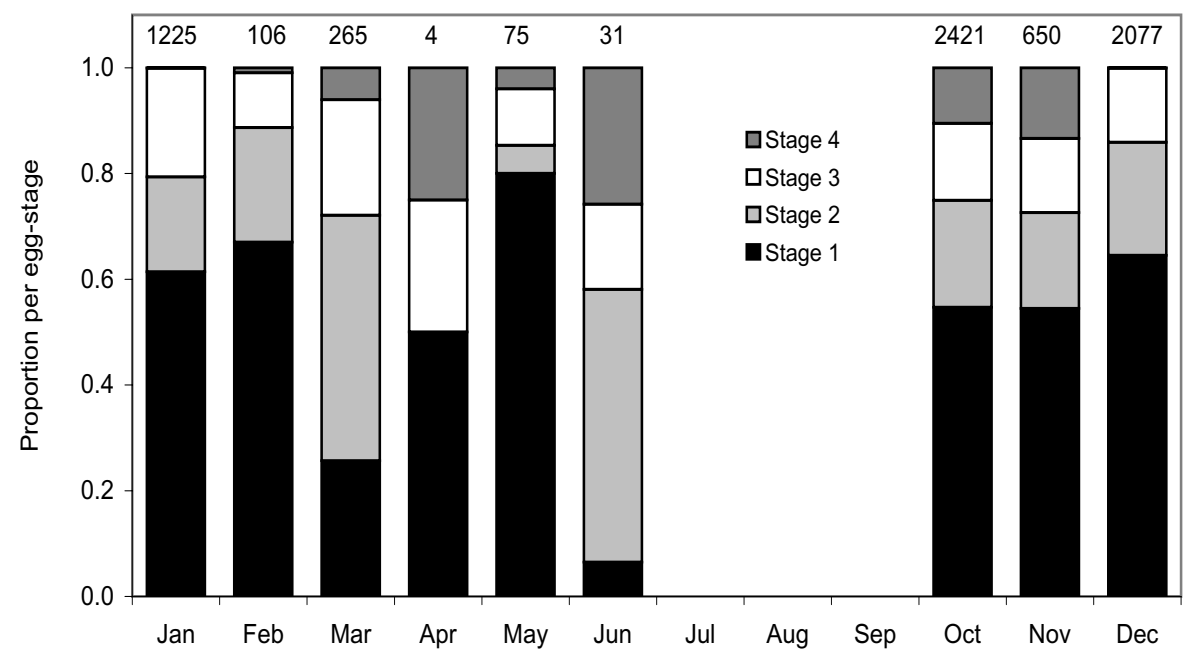

Figure 5. The proportions of all females with eggs in developmental stages 1-4 in each month. No samples were available for July-September, and sample sizes are shown.

May/June to January/February ( 9 months), with a short pause between February and April. This pattern conforms with the general pattern shown for tropical palinurids (i.e. year-round breeding or an extended reproductive period with multiple spawnings), which is facilitated by warmer water which physiologically accelerates gonadal development, and protracts the spawning period (Berry, 1971; Chubb, 2000; Phillips and Melville-Smith, 2006).

Water temperature and seasonal progressions in day length and/or water temperature are the obvious triggers governing the onset and conclusion of breeding seasons in lobsters, although these influences have not been explored in many species (MacDiarmid and Sainte-Marie, 2006). Panulirus homarus off eastern South Africa showed a similar 9-month breeding season to those in Oman, extending from June/July (austral winter) through spring and summer up to autumn (March), with the highest levels when water was warmest in mid-summer months (Berry, 1971). A sharp drop in egg-bearing proportions occurred when water temperatures declined in March or April (Berry, 1971). Conversely, in larger females first breeding activity was recorded in June/July when water temperatures were at its lowest levels. Jasus edwardsii mating in New Zealand also appears to be triggered by an autumnal decline in temperature (MacDiarmid and Sainte-Marie, 2006).
The onset of breeding in Oman in May/June coincides with the onset of the SW monsoon conditions in the Arabian Sea region. During the SW monsoon, the prevailing wind conditions generate a coastal upwelling, resulting in cool, nutrient rich coastal waters with a general northeastward flow - the Oman Coastal Current which may extend $200 \mathrm{~km}$ offshore and attain a speed of $0.4 \mathrm{~ms}^{-1}$ (Elliot and Savidge, 1990; Kindle and Arnone, 2001). During this period the temperature decreases from an average of $29^{\circ} \mathrm{C}$ in May $\left(26^{\circ} \mathrm{C}\right.$ in June) to $21^{\circ} \mathrm{C}$ in September before increasing again to $26-28^{\circ} \mathrm{C}$ by October to November (Thangaraja, 1995). We suggest that the drop in water temperature at the onset of the SW monsoon may trigger the onset of synchronous breeding, particularly in large females (see Fig. 3), although the influence of other intrinsic and environmental factors are almost certainly also important.

Although the change in water temperature may initiate synchronous breeding in May/June, the breeding season extends throughout the cooler water SW monsoon period, and also through the warmer water intermonsoon (mid-September to October) and NE monsoon (November to mid-February) periods. The prolonged breeding season is therefore sustained by factors other than temperature alone - and an obvious candidate is the availability of food, both for adults and hatched larvae. The initial 
increase in nutrients and primary productivity during the upwelling of the SW monsoon is followed by an increase in zooplankton biomass in the Arabian Sea in September/October to February (Thangaraja, 1995), and presumably the higher productivity during this period and the concomitant availability of food plays an important role in the timing and duration of the reproductive season. A similar conclusion was reached by Berry (1971), who suggested that the annual reproductive cycle of South African P. homarus was geared towards production of larvae when productivity on the continental shelf off eastern South Africa was at its maximum. Relationships between upwelling and reproduction were also reported for spiny lobsters Jasus lalandii off the west coast of South Africa (Kanciruk, 1980) and Panulirus interruptus along the west coast of Mexico (Vega, 2003).

The catchability of $P$. homarus in shallow water declines sharply in February (pers. obs. JCG), and few females caught between February and April carried eggs (see Fig. 3). The scarcity of lobsters in fishing gear during this period suggests that they have migrated to deeper waters, or are not moving around and feeding as actively as before. The cause for this behavioural change is not apparent, however it does coincide with increasing water temperatures prior to the onset of the SW monsoon and generally more oligotrophic conditions in the Arabian Sea (Thangaraja, 1995).

Seasonal closures, usually around the time of breeding, are a well-utilized regulatory measure in spiny lobster fisheries, and apart from reducing fishing pressure, well-timed closures can prevent disturbance to breeding populations at a critical phase in their life cycles (Chubb, 2000). Furthermore, the importance of egg-production in exploited lobster populations has recently been highlighted by Miller (2003), who suggested that increasing the number of eggs produced by a population has the potential to increase yield manifold.

Although the level of egg-production by $P$. homarus in Oman relative to pristine is not known, the size structure of populations, and therefore the abundance of large highly fecund females, has declined sharply over recent years (Al-Marzouqi et al., 2007). Management measures to increase eggproduction are therefore pertinent, and the existing open fishing season between $15^{\text {th }}$ October and $15^{\text {th }}$ December falls within the peak reproductive period.
The results of this study suggests that an open fishing season would be better placed in February to May, when few females carry eggs. The absence of any notable spatial variation in the reproductive season among sites indicates that a single open season for all the fishing sites along the Arabian Sea coast of Oman would suffice, and that zonal closures (see Vega, 2003) are unlikely to be advantageous.

\section{Acknowledgements}

The Agriculture and Fisheries Development Fund of the Sultanate of Oman funded this study and we thank H. Al-Oufi, A.H. Al-Hosni, and I. Al-Busaidi for their role in securing the funding. I. Anbory, H. Al-Waeli, E. Al-Rasadi, S. Rabeea, M. Al-Hatroshi, R. A-Senaidi, J. Al-Jafari and S. Obeed are thanked for technical support and collection of data and biological samples on field trips.

\section{References}

Al-Abdessalaam, T.Z.S. 1995. Marine species of the Sultanate of Oman: An identification guide. Ministry of Agriculture and Fisheries, Marine Science and Fisheries Centre, Sultanate of Oman. Muscat Printing Press, 412 pp.

Al-Marzouqi, A., A. Al-Nahdi, N. Jayabalan, and J.C. Groeneveld (in press). An assessment of the spiny lobster Panulirus homarus fishery in Oman - another decline in the western Indian Ocean? Western Indian Ocean Journal of Marine Sciences (2007).

Anon., 2006. Fisheries Statistics Book (2005) for the Sultanate of Oman. Directorate of General Planning and Investment Promotion. Statistics and Information Department. Ministry of Agriculture and Fisheries, Muscat, $240 \mathrm{pp}$.

Berry, P.F. 1971. The biology of the spiny lobster Panulirus homarus (Linnaeus) off the east coast of southern Africa. Investigation Report of the Oceanographic Research Institute of South Africa, 28:1-75.

Chubb, C.F. 2000. Reproductive biology: Issues for management. Chapter 14. In: Spiny Lobsters: Fisheries and Culture, $2^{\text {nd }}$ edition. B.F. Phillips and J. Kittaka (Editors), pp 245-275. Fishing News Books, Blackwell Science, Oxford.

Elliot, A.J. and G. Savidge. 1990. Some features of the upwelling off Oman. Journal of Marine and Freshwater Research, 48:319-333. 
Holthuis, L.B. 1991. FAO Species Catalogue. 13. Marine Lobsters of the World. An annotated and illustrated catalogue of species of interest to fisheries known to date. FAO Fisheries Synopsis, 125(13):292 pp.

Johnson, D.W., and T.Z. Al-Abdulsalaam. 1991. The scalloped spiny lobster (Panulirus homarus) fishery in the Sultanate of Oman. The Lobster Newsletter, 4:1-4.

Kanciruk, P. 1980. Ecology of juvenile and adult Palinuridae (spiny lobsters). In: The Biology and Management of Lobsters, J.S. Cobb and B.F. Phillips (Editors), pp 59-96. Academic Press, New York.

Kindle, J.C. and R.A. Arnone. 2001. A review of the surface circulation of the northern Arabian Sea. In: Proceedings of the 1st International Conference on Fisheries, Aquaculture and Environment in the NW Indian Ocean. M. Claereboudt, S. Goddard, H. Al-Oufi, and J. McIlwain, (Editors), pp 113-122, Sultan Qaboos University, Muscat, Sultanate of Oman.

MacDiarmid, A.B. and B. Sainte-Marie. 2006. Reproduction: Chapter 2. In: Lobsters: Biology, Management, Aquaculture and Fisheries, B.F. Phillips (Editor), pp 45-77, Blackwell Scientific Publications, Oxford.

Miller, R.J. 2003. Be-all-you-can-be management targets for Canadian lobster fisheries. Fisheries Research, 64:179-184.

Mohan, R., 1997. Size structure and reproductive variation of the spiny lobster Panulirus homarus over a relatively small geographic range along the Dhofar coast in the Sultanate of Oman. Marine and Freshwater Research, 48:1085-1091.
Phillips, B.F., and R. Melville-Smith. 2006. Panulirus Species: Chapter 11. In: Lobsters: Biology, Management, Aquaculture and Fisheries, B.F. Phillips (Editor), pp 359-384. Blackwell Scientific Publications, Oxford.

Radhakrishnan, E.V., V.D. Deshmukh, M.K. Manisseri, M. Rajamani, J.K. Kizhakudan, and R. Thangaraja. 2005. Status of major lobster fisheries in India. New Zealand Journal of Marine and Freshwater Research, 39:723-732.

Siddeek, M.S.M. 1999. Marine fisheries resources, fisheries and marine environmental management, coral reefs and marine parks in the northwest Indian Ocean. Report of a Regional Workshop on Fisheries Monitoring, Control and Surveillance, pp 101-115. Muscat, Sultanate of Oman, 24-28 October 1999.

Thangaraja, M. 1995. Hydrobiology off Oman. MSFC Research Report 95-1. Marine Science and Fisheries Centre, Muscat, Oman, 153 pp.

Vega, A.V. 2003. Reproductive strategies of the spiny lobster Panulirus interruptus related to the marine environmental variability off central Baja California, Mexico: management implications. Fisheries Research, 65:123-135.

Vijayakumaran, M., T. Senthil Murugan, M.C. Remany, T. Mary Leema, J. Dilip Kumar, J. Santhanakumar, R. Venkatesan, and M. Ravindran. 2005. Captive breeding of the spiny lobster, Panulirus homarus. New Zealand Journal of Marine and Freshwater Research, 39:325-334.

Zar, J.H. 1984. Biostatistical Analysis. Englewood Cliffs, N. Jersey Prentice-Hall Inc. 620 pp. 